\title{
Historical Evolution of Placemaking in Historic City of Palembang, Indonesia
}

\author{
Muhammad Fajri Romdhoni, ${ }^{1,2}$ \\ ${ }^{1}$ Department of Architecture and Design, University of Kansas, USA \\ ${ }^{2}$ Program Studi Teknik Arsitektur, Universitas Sriwijaya, Indonesia \\ muhammadfajriromdhoni@ku.edu /muhammadfajriromdhoni@unsri.ac.id
}

\begin{abstract}
This paper aims to present Palembang's city's historical evolution into clear morphological phases of the city due to the rapid transformation of Southeast Asian cities with modernization and westernization. Palembang is essential because it represents one of the earliest and historical cities in Southeast Asia and could serve as a good case study to the morphological changes in Southeast Asia. Studies selected for this paper are historical maps on the 17th century, a combination and sets of the early 19th century, and post Indonesia's independence maps that include the latest map of the modern Palembang city. A historical and interpretive study framework was conducted and implementing the maps using GIS and OSM as the newest data source and analysis. Using Placemaking theory and utilizing Street pattern, Land use, and landmark as an approach tool to clarify the city's spatial form. Analysis of street patterns, land use, and landmarks was carried out on the three different morphological phases, and we founded out that there have been changes in the quality of place over time. The city form has shifted more complex from a linear settlement and transform into a co-centric form city and later on morphed into a multiple-centered metropolis. The land use had also changed over time due to political, economic conditions, and dwelling pattern. Palembang city's landmarks have also evolved or multiplied over time, and it has given the evolution of meaning to the city. From the changes in the quality of place and geographical model transformations, future studies will need to focus on increasing the quality of place by classifying the city's spatial configuration from its integration, betweenness, and choice that could define the city's network and systems. Future studies will also need to compare the research findings with other cities in the Southeast Asia regions with similar conditions to create a comparison between the results and a better understanding of Historic Southeast Asian cities.
\end{abstract}

(C) 2020 IJBESR. All rights reserved.

Keywords: Palembang, Street pattern, Land use and Landmark, Placemaking, Morphological Phases.

\section{Introduction}

The City is not only an artifact but also a living process. The growth of a city is often the result of organized complexity. A new city built from a plan will lack meaning and life, but cities degenerate into sprawl without a plan. Primarily it is shown that development in the historic City is proven to be a more difficult challenge. Finding the right composition of order in complexity in a continuous change and policy is urban designers' task. It is a demanding subject, but with the correct theory and tool, a thoughtful and planned city could be decisive to create a good and successful city. Many urban design theorists have been creating theories about the general form of cities based on their development [1]; urban development [2]; the basic form of cities[3]; the evolution of cities, the social and cultural development of cities, the study of city form, etc. [4, 5]. Changes in urban development are inevitable, but as Jane Jacobs describes that the City will not freeze in any development. Still, it needed the composition with the orderly whole to manage and maintain the City's livelihood [6]. 
A historic city must be treated in a precise, careful manner and thoughtful process that could describe the City's historic urban fabric and assess the best policies to create an excellent historical city development.

Over the year, there have been theories of creating a good city and the importance of the sense of place. The concern of physical quality places among the essence, with the design styles, ornamentation and featuring as the rational classical view of urban design [7]. Creating a successful city is a multidimensional effort, not only about the physical qualities of form but also on two other aspects such as the activity of the place and image that the City gives. A city is not only a physical space, but it is also a psychological space that should give the feeling of a comfortable, vibrant, quiet space, and even the sense of safeness [8]. The fundamental theory of urban design is a combination of form, image, and activity. These variables will provide the structure and underlying dynamic activity that the City needs. Urban design is primarily about placemaking, where places are not just a specific space, but all the activities and events which made it possible [9]. Reflecting on the traditional spatial pattern that has been laid out for the historic City could be proven beneficial for the activity and meaning to support the urban form and historical evolution of the City.

Defining the historical evolution of the City is very important to understand the future development of the City. Defining a balance between order and complexity could be achieved if the layering of the City's urban fabric is understandable. The co-relationship between research, development, and analyzing the movement pattern will enhance the importance of the City in general. Mapping of morphology and development of the town could see the evolution from many aspects, such as political, economic, historical, social, ecological, and the cultural transformation of the City [10]. However, the transformation of historic cities in developing countries is rapidly changing. The lack of understanding of the historical importance, an unclear connection between the historic City and modern City, will result in the inability to create the appropriate sense of place.

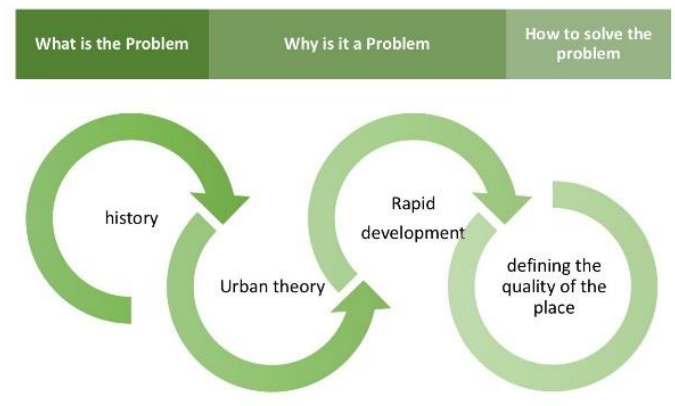

Source: Author, 2018

Figure 1. Framing the research questions

\section{Research Methods}

The research focuses on Palembang's morphology and the importance of placemaking through the morphological phases of the city. The study compares transformational stages of the city from historical maps and data in combination with the use of GIS / Geographic Information Science technology. The data was collected from OpenStreetMap, where the GIS data map's accuracy is relatively high $[11,12]$.

The observation and analysis are used by a comparative study between the visual data representation provided by the GIS software ArcMap with theoretical analysis from Placemaking. Street pattern, Land use pattern, and Landmark describe the Form, activity, and Image of Palembang and how the city has changed over time.

In addition, the research also verifies the earlier city form that was adapting the colonial port cities, and that has shifted and transformed to a multiple-centered city due to the addition of 
newer landmarks and the increase of administrative area.

\subsection{Place Making Theory: Form, Activity, Image, and City Morphology}

Placemaking is essentially an effort to create a successful place, where people know that this is the right place. It isn't easy to understand why a place is successful and how the right conditions generated a successful place. Many tried to describe and create an indicator for a successful place [4]. Sherman has provided a list of qualities or characteristics of successful urban areas, but it is essential to fully understand what a place is and how the theory will impact the city. It is John Montgomery in his paper on Making a city that disseminates the urban theorist and argues of successful urban places are based predominantly on street life and various ways in which activity occurs in and through buildings and spaces. This argument is also supported by [2]. According to John Montgomery (1998), placemaking includes three aspects of form, activity, and image, and a balance of the three aspects will promote a successful place. Urban design is essentially about placemaking, where places are not just a specific space, but all the activities and events which made it possible [13]. By balancing the three variables of placemaking, the urban design process will presumably create a successful city.

The first aspect of Placemaking, according to Montgomery, is formed. It is the physical shape of the city that includes all the attributes related to the city. The city's form can be valued from the buildings, landmarks, building to space ratios, scale as also suggested by [1], The City Shaped: Urban Patterns and Meanings Through History. If a city is regular and homogeneous, there would be no forces, and in conclusion, there is no form. The form is the result of functional origins that is achieved from a conscious decision and careful thought. But form could also be the result of the natural process by solving and fulfilling the city's spatial need. There have been many theories about a good city form [4]. This paper will apply a clear understanding of form in the urban scale, and it can be viewed with the street network figure-ground diagrams, a la Allan Jacob's Great Streets [14]. The figure-ground diagrams are a standard tool in urban planning and design to represent the relationship between built and unbuilt space. The street pattern as one of the figure-ground products is a tool to analyze the complexity, pattern movement, legibility; knowledgeability also draws a conclusion on people's presence on a specific town plan. The street pattern is also a useful tool to show the form of the city to define the tree, linear pattern, or grid of the city; this method is shown to define the phase of the city as shown on [15] the study also shows the need to contain historical part of the city to maintain the movement density because of the fragility of historical district. The street pattern changes show the effect on density, pattern, and the direction of the urban growth and define the relationship between syntactic historical forms of the city from an organic nucleus to a huge metropolitan city.

The second aspect is the activity that shows the street life, people, cultural aspect, events, and local traditions and attractions that is happening in the city. Cities need a mingling of old buildings to cultivate primary-diversity mixtures, as well as secondary diversity. In particular, they need old buildings to incubate new primary diversity. This will promote activity with diversity that could create street life, security culture, and growth in the economy. Diversity then creates a mixture of components that will influence the city's vitality [16]. As explained by Jane Jacobs, old buildings and history are the primary ingredients to create diversity. An old building will take tens and hundreds of years to create the image and promote the city's activity. Diversity is also an ingredient that promotes economic, social, and cultural growth [17]. 
There have been studies on representing activities and exploring the settlement and earlier town forms [18-20]. The studies show that urban form relates to the activities, subject to relatively rapid changes. A land-use pattern is a way of interpreting the activities conducted in the city's specific area and zone and ways to know the causal relationship of changes to the activity. Conzen has shown in his town-plan analysis the concepts and methods to explore the transformation such as urban fringe belt, burgage cycle, morphological frame, morphological region, and morphological period. The Urban fringe belt defines and the land use of the edge of the urban area and a way to see the outward growth of a town - the burgage cycle a method and analyzing the measurement plot to reconstruct historical plots. Simultaneously, the morphological frame, region, and period are Conzen's method and technique to define the outline of the city, a concept of an area that creates unity and classifies the timespan on which morphology of a region that remains unchanged [21].

The final aspect of making a city is an image, which is the intangible result of activity and form. This city's image is a cognition perception and information of a city. The image consists of symbolism and memory, sensory experience, knowledgeability, and psychological access to the city. Among those aspects that are widely known by urban designers are imageability and legibility. Imageability is the physical object's quality that has a strong image that can easily be identified by the observer. Legibility is the ease with which a reader can recognize the individual character of the city. According to Lynch, the city's components are the path, node, edge, district, and landmark, where each component plays a part in creating the cityscape that can be read by people who move through the city [22]. Also, many urban theorists emphasize the importance of the city's image [23, 24]. In this paper, I will be focusing on a landmark as an architectural form that shapes the image, symbolism and perception of the people who lived in the city. According to a particular context and condition, landmarks may have doubled, changed, or even demolished on each phase's morphological. The remaining milestone tends to have deep meaning with the inhabitant, thus shaping their perception of the city. These three aspects of placemaking have a close relationship with one and another. Form, activity, and image should be analyzed thoroughly and interpreted to see the relationship to create a successful city.

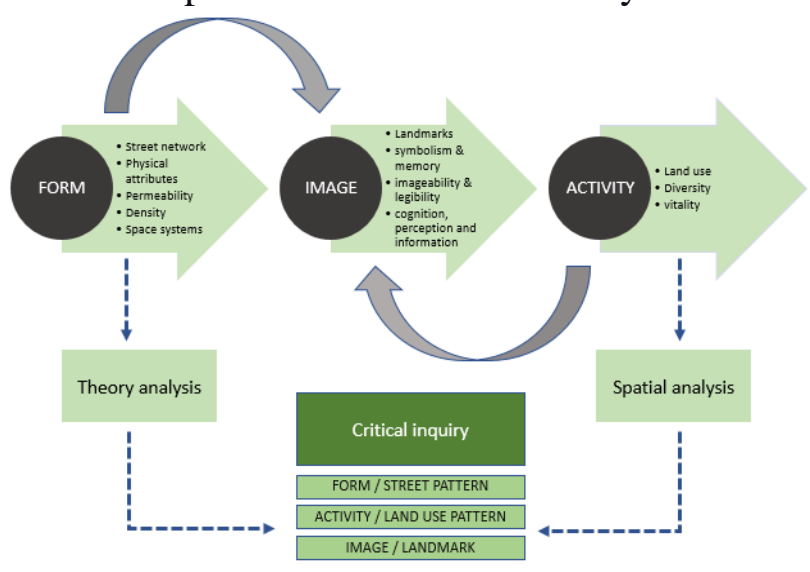

Source: Author, 2018

Figure 2. The conceptual framework and thought experiment of the research

By understanding the urban morphology and the placemaking theory this paper could reveal the urban fabric of the city and the historical evolution of the built environment. The morphology and transformation is caused by various reasons, particularly because of the change of power, economy and political views that changes overtime. Nevertheless, the original form will affect the future transformation of the city. The historical elements and traces of the past lives should always be respected and will become an important lesson for the future [25] [26]. The study of the historical evolution on this research will be focusing on the complexity of the street pattern, the diversity of activities in the land use and the symbolism and memory of the landmark. 


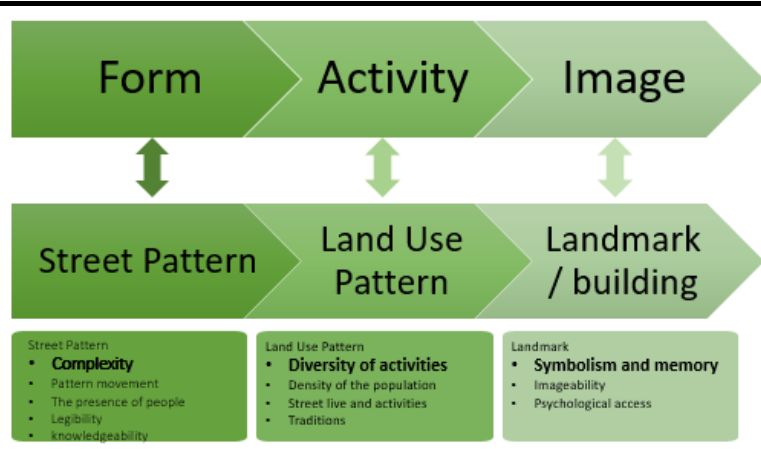

Source: Author, 2018

Figure 3. Methods and tactics to verify the placemaking theory

\subsection{The Geographical Model of South Asian Cities}

This research also studies the spatial model implemented on Southeast Asian cities using the Sriwijaya Empire and Palembang case study narrative. There has been researched that studies the geographical model of South Asian cities using three colonial port cities in India. The research analyzes the spatial configuration of the cities and creating a geographical model [27].

This geographical model shows that colonial port cities were developed from European mercantile cities and modified to accommodate the local inhabitants by providing settlements in the industrial sector.

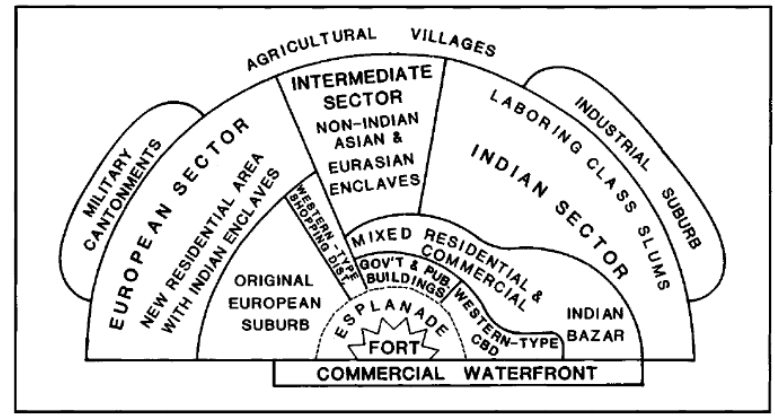

Source: M. Kosambi and J.E. Brush, Three colonial port cities in India, Geographical Review 78 (1988) 34.

Figure 4: The schematic model of Colonial port city

The new research shows the hierarchical model of the town, verifying the initial model. This research's geographical model could be verified if a similar model was also used in Southeast Asia cities. Finding the city's geographical model is essential for the morphological region and knowing the historical town's boundaries. By knowing the boundaries than the development of a historical city could maintain the continuation in function, space, and community and prevent the city from becoming historical theme parks or slums [10] [30] [31].

\subsection{A Brief History of Palembang and Its Historical City}

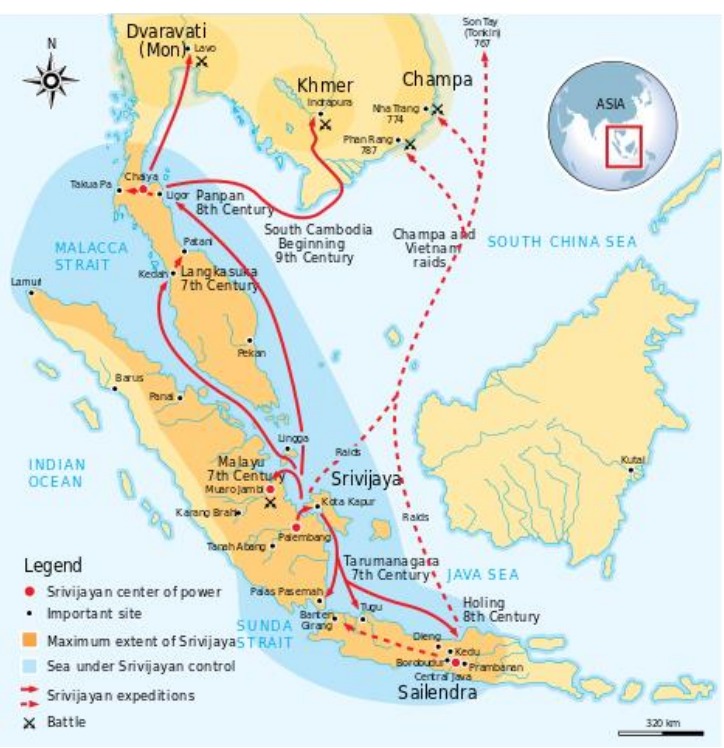

Source: Map downloaded from Wikipedia, 2018

Figure 5: The Sriwijaya Empire connecting the

Sumatera Island, Java Island, Singapore, Malaysian

Peninsula, Thailand, Burma, Cambodia and Vietnam.

Palembang, the oldest extant city in Indonesia, dates back to $682 \mathrm{CE}$, and the city has a long and significant history farther back in time. Palembang is associated with the Sriwijaya Empire known as shahbandar or the "port-master," Shahbandar was a metropolis in the past as it is today, and a destination for foreign merchants trade, politics, and cross-cultural interactions with neighboring Empires [32]. The major Southeast Asian islands that possessed the shahbandar are Sumatra with the city of Palembang in the seventh century, Malaysia with the city of Malacca in the 1500s, and 
Sulawesi colonial trading city of Makassar in the eighteenth century [33].

These major port cities and vital trading routes connected Southeast Asia with traders from China, the Middle East, and Persia. The Sriwijaya Empire expanded from the Sumatera islands, linking the Malay Peninsula with Thailand and Burma, and merged many nations. Although the center of Sriwijaya remains controversial, an inscription supports Palembang's concept as an essential part of the Empire. The inscription is written in an ancient tablet known as the Kedukan Bukit that dates the city from CE 604 Saka (682 AD). In 1930, another inscription, Telaga Batu, known by natives as Sabokingking, and supports the central hypothesis and the substantial historical part of Sriwijaya and Palembang [34].

The Sriwijaya Empire lasted for nearly eight centuries, and later on, the Palembang town was under the Majapahit Empire's political governance. The city's political rule was then transferred during the Islamic Empire under the Kesultanan Demak that has strong Islamic influence. This Islamic Empire ruled for 366 years from $1455 \mathrm{CE}$ to 1821 as Kesultanan Palembang Darussalam. Palembang's initial city plan was laid out with Keraton Kuto Besak as the city center and Keraton Kuto Gawang as the Islamic Empire's Palace [35]. During the reign of Kesultanan Palembang Darussalam, the city of Palembang adopted Uluan and Iliran (Uluan is the River source / River mouth's location Iliran is the location of the River end). The Musi River divided the city into two: Hulu and Hilir. In Hulu, boats dock and are located on the south side of the Musi River. Hilir is for the Palace and settlements and also a place for the bazaar economy. Differences between the settlers and the Dutch oppressors were rising in 1737 under the rule of Sultan Mahmud Badaruddin the 1st that was dissatisfied with the Dutch's unjust and oppressing manner. The Dutch East India
Company, VOC

(Vereenigde Oostindische Compagnie / VOC also known as the Dutch East Indies Company) later forced the monopoly to control Palembang's trade that sparked a new feud in the city of Palembang. The Predecessor then continued the rule of Palembang Darussalam, known as Sultan Mahmud Badaruddin II. He transformed the city into fortresses to protect the town from aggressors, especially the VOC. At least five main strongholds existed, Benteng, Kuto Besak as the palace / Keraton that was transformed into

a fortress, Benteng Sungsang and Benteng Salanama on the estuary, Benteng Kemaro, and Benteng Gamboro. The battle between VOC and Kesultanan Palembang Darussalam continued until 1821, and afterward, the governing of Palembang city was controlled by the Dutch Indies Company.

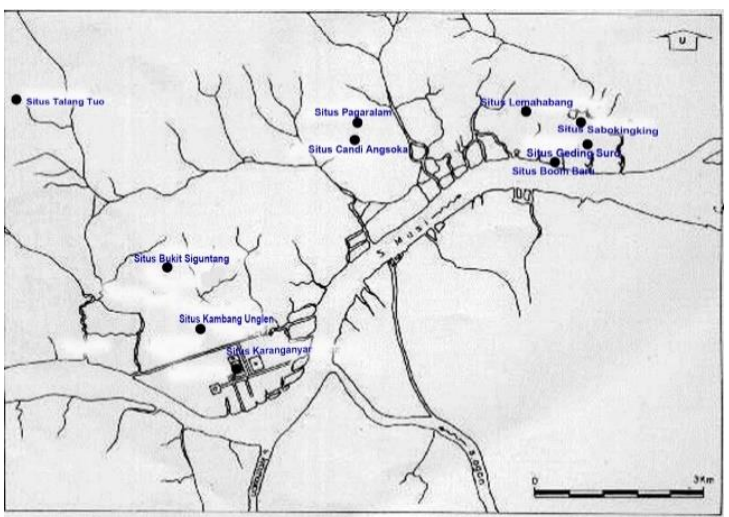

Source: http://www.himapes.com/2016/04/palembangdan-sriwijaya.html on November 2018

Figure 6: The remnants of the Sriwijaya Empire in the city of Palembang.

In the establishment of The Dutch East Indies Company / VOC in Palembang, the city continued to grow on both the Hulu and the Hilir part of the town. The Hulu connects the city with traders from the outskirts, with plantation goods, herbs, spices, and plants, while the Hilir part is transforming from the Kesultanan Palembang Darussalam into a Colonial port city. During colonialism in Palembang, there were numerous building and road constructions in Palembang, and some 
Rivers that were meant as transportation ways connecting the town was closed down, creating a new spatial form to the city [36].

The initial layout of the city was derived from the classical schematic model of the colonial port city. The city's principal component is the fort, alongside the Musi River and adjacent to its commercial waterfront. The town's plan was developed of layering from ports, esplanade, government buildings, first European suburb and the dividing of the industrial suburb and laboring class slums. The schematic model shows that Palembang resembles a colonial port city derived from European mercantile cities [27]. The colonial port city model shows that the European model of the mercantile city needed to change and adapt to provide space for a mutual relationship with the native settlers.

The next stage of Palembang's development was after Indonesia's independence in 1945 that integrated the Hulu and Hilir parts of Palembang with the erection of the Ampera Bridge. The city later transformed from once a River city and now a city that is more integrated with roads and streets that connected the parts of the city. Under President Soeharto's new Indonesian government, the town grew and expanded towards the city's hinterland and northern parts with building and road construction. The government had instructed the political notion of nationbuilding with infrastructure construction, and Palembang is the capital city in the west of Indonesia that has benefited from the government's program. During Indonesia's independence, Palembang's city tried to regain back the historical traces of the Sriwijaya Empire. The close relationship to Sriwijaya was later confirmed by the tablets of kedukan batu and sabokingking that has led to modern archeological excavation in the city. A large archeological site was also founded in Palembang in 1984 called the Karanganyar site on the edge of the Musi River. The site was believed to be a garden in the time of Sriwijaya with waterways, reservoirs, and floating islands that connects with an ancient burial site in Bukit Siguntang. Besides the archeological site, the excavation in the area also discovered fragments of pottery, ceramics, beads, and brick dated back to the 7 th century. During this time, the city of Palembang is trying to regain and associate the city with the Sriwijaya Empire's glory. The city uses the slogan as Bumi Sriwijaya or the center of Sriwijaya as a notion of pride that it has a tremendous ancestral background and a part of a vast and glorious empire [37].

Now Palembang has evolved into a metropolis. A new center of Jakabaring sports city has been the primary destination of Palembang, and the physical aspect of the town has transformed rapidly. The population of Palembang in 2016 exceeds 1.676.544, compared to 878.732 in 1986. The population has doubled in 20 years. The earliest population estimation is approximately 50.703 lives in 1905 during the colonization era. In 1986 the government expanded the city territory from $224 \mathrm{~km} 2$ to $400,61 \mathrm{~km} 2$, and the city limits have been changing over time. Geographically, the city is dominated by lowlands and Rivers, but most Rivers are filled after modern development, and new buildings and facilities are being erected. Palembang's geological structure, which was once $60 \%$ lowland, is now only $40 \%$ lowland because of the city's rapid changes. New problems have arisen in the contemporary metropolis of Sumatera, Indonesia. 


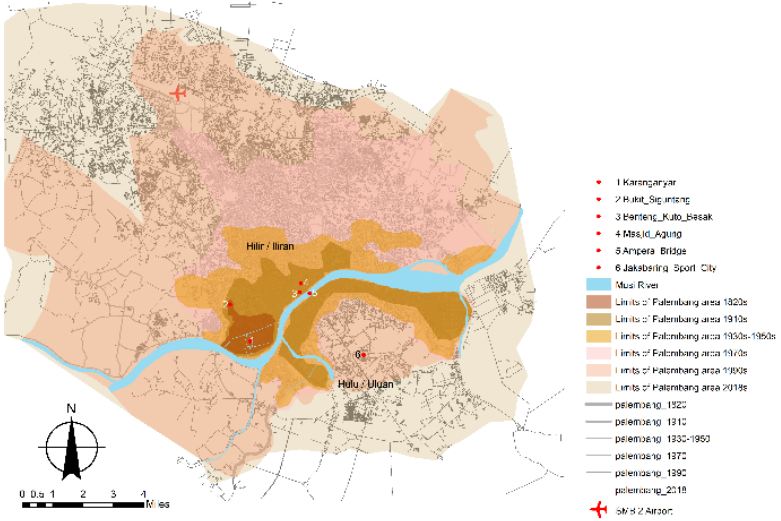

Source: Author, 2018

Figure 7. The map shows the main feature and historical morphological phases of Palembang.

\section{RESULTS AND DISCUSSIONS}

\subsection{Spatial analysis and the importance of traditional city}

For the morphological evolution of Palembang's city, this study has collected maps of Palembang in the following year: 1821, 1917, 1922, 1930, 1945, 1970, 1990, and 2010. After analyzing the spatial configuration from the different years. The findings of the spatial differences in the city of Palembang, I concluded that the urban morphology of the town is divided into three different phases:

- The first morphological phase is used to describe the Dutch colony's invasion in 1821; the map shows the different forts protecting the city of Palembang. This map shows the earliest form of the town Palembang, and the map shows the location of the important Sultanate Palembang Darussalam building as opposed to the important Sriwijaya Empire archeological site's

- The second morphological phase of the city began in 1917. During the Dutch Indies Company settlement in Palembang, and at this era, there were numerous changes in the city configuration. The maps that are used to identify these changes are the 1922, 1930, 1945 maps. The Dutch colony ended in 1945 when Indonesia gained its independence. This map shows the transformation of Palembang's city, and important historical landmarks that Palembang has today are related on this map.

- The third morphological phase is the modern transformation of Palembang, which started from the integration between Uluan and Iliran parts of the city with the Ampera Bridge, which was open for public use in 1965. The map supporting this era's spatial configuration is 1970,1990 , and 2010 maps and the most recent map acquired from OpenStreetMap, an online open-source map website. This map shows the modern transformation of Palembang, and the high complexity of the pattern is created during this morphological phase.

\subsection{Street Patterns / Form}

Figure 8 shows the map from the earliest source that I could acquire. The map shows that the earlier known spatial configuration of Palembang was built during the Sultanate Palembang Darussalam. In this era, the Sultan built five forts to defend the city from outside invasion. The forts were connected with a linear pattern street as a way to reach the forts. During this time, the city is also joined by boats as the means of transportation, and the Rivers connected to the other parts of the town were well preserved. There is little complexity on this map. However, this map reveals the correlations of the historical Sriwijaya Empire with the Sultanate Palembang Darussalam. This map showed that the center of Sriwijaya was the Karanganyar site, while the center of Sultanate Palembang Darussalam was the Keraton Benteng Kuto Besak. 


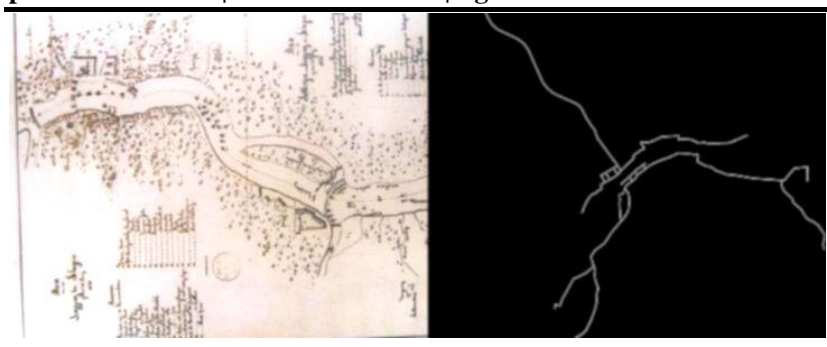

Source: Author, 2018

Figure 8: earliest source of the classical map on Palembang dated 1821, during the Dutch East Indies invasion to the city of Palembang. The settlement pattern was a linear pattern connecting the city with other important places in the region.

Figure 9 shows the city's transformation into a concentric and radial form, and the Dutch colony occupied the town at this morphological phase. From the roads' spatial pattern, we could see that the city has a combination of the linear pattern along the River line and a center that shows the point of activity. The linear pattern connected between ports along the river shores while the radial lines connected to the town's outer suburbs. The city was transforming into a Colonial Port City, a geographical model that was suggested by Hornsby. It shows a similar pattern of East Indies cities even though the VOC colonized Palembang. The form also indicates a new concentration on the eastern part of the town, which is called Peladju, which transforms into an Oil refinery during the rising oil industry in the 19th century.

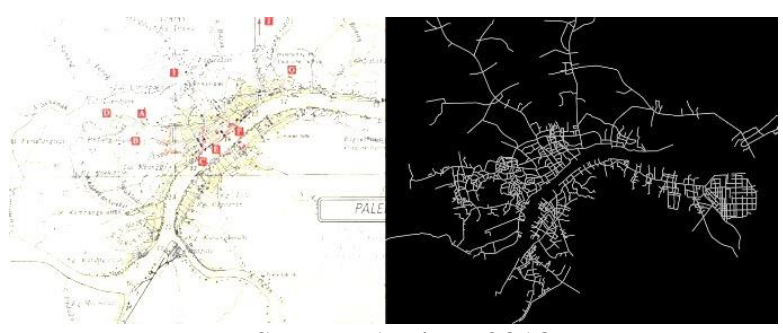

Source: Author, 2018

Figure 9: the map of the colonial occupation 1821-1945 shows that the city started to transform from linear pattern into a radial pattern acquiring the colonial port city pattern to the city

Figure 10 shows the current condition of Palembang. The city form has transformed and change into a metropolis, and the spatial configuration form has change into multiple centralities. There are numerous landmarks in the city, and the district also has changed and transformed into various point, not just the heritage district but also a new district that offers modernity and recent activity, such as at the south of the city there is a new sport district to support the government program to turn Palembang as a sport city. The hinterland part of Palembang is also evolving with new destinations for the town.

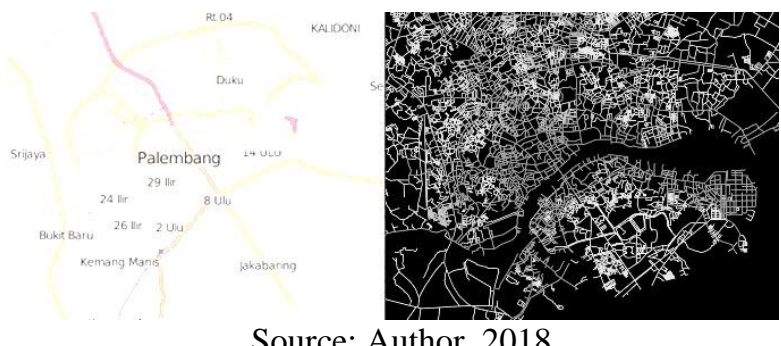

Figure 10: the modern map of Palembang shows that the city has transformed into a multiple centrality pattern

From the morphological evolution map, we could see that the street pattern has changed from a linear settlement and changed into a radial form street network and transformed again into a multiple centrality metropolis. The complexity of the street pattern has changed dramatically and affecting the pattern of the city. Over time, the transformation has created a new path, node, edge, districts, and landmarks for the town.

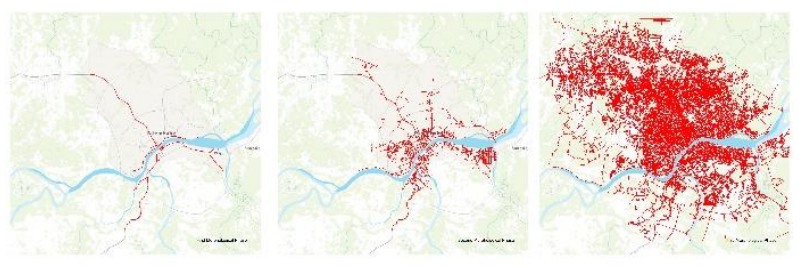

Source: Author, 2018

Figure 11. Street Pattern morphological map of Palembang.

From Figure 11, we could see changes that responded to the city's historic area, but some changes do not respond to the historic site. Historical places created the form of the town that is being neglected, especially the old Sriwijaya historic district of Karanganyar. 
Although the changes have created more vibrancy and diversity in the urban environment, urban sprawl and uncontrolled growth have created new problems for the metropolis' fast growth. From this finding, we could conclude that the historic part of the city is less placemaking, which could worsen if the street pattern and street connectivity are not carefully planned. To main the liveliness part of the historic town, then the connectivity should be well contained and given constraints and control the access.

\subsection{Land Use Patterns / Activity/ Landmarks / Image}

During the first morphological phase of the city of Palembang, the town's main activity was agriculture and trading, and the Sultanate was the political order that governs the everyday life of the city. The city of Palembang was a mixture of people from the Java island of Majapahit Empire and the indigenous people of Palembang. Mix culture between the two tribes resulted from a port city that adds up to the mixture of other races and nationalities such as the Chinese and Mediterranean race of Arab, Persia, and India. The traditional culture of this mixture created unique settlements along the Musi River. Houses and villages were stretched following the linear settlements along the River. The land use pattern shows that the Sultanate Palembang Darussalam is located on Benteng Kuto Besak and the reminiscent of Sriwijaya located in Karanganyar.

The city's activity was being diverted on the second morphological phase, focusing on the River and turned to activate the hinterland with the government center and public facilities. As a colonial port city, the trading activities were very active at that time, and new and modern facilities were needed for the town. The main event of governance and trading was alive during the second morphological phase. The port activity and bazaar market were very much the daily lives of the people who live in
Palembang. During this morphological phase, the city tasted globalization and mixed culture with European society. The European language was diversely learned, and the Dutch style of clothing and buildings were implemented all around the city. The marketplace was transforming from the bazaar market into store shops and shopping arcades. The town has become centralized around the ports, and new facilities and activities were located in a radial form around the harbor. The land use pattern shows that the second morphological phase has similarities with the colonial port city, proposed by [27] where the facilities shape around the main port. The military cantonment is on the edge of the town.

The third morphological phase has a much more diverse activity throughout the city. Since the integration between the Hulu and Hilir part of the city, Palembang's activity has rapidly increased. The city's multi-central points also created a new activity in every district from social and street life activity, and the commercial activity had also increased in dispersing into other parts of the city. Modern activity and the erection of shopping malls has also affected the daily life of the city dwellers. The land use pattern shows that the local housing is being dispersed into the edge of the city, and new commercial centers are emerging. In this phase, a new region of sports facilities is established, but the region of the historic Sriwijaya Empire of Karanganyar is neglected, filled with new local housings.

From the morphological phase of the land use, we could see that land use in the modern city of Palembang needed more diversity. The inner core of the city is growing with diversity and mixed complexity. Still, the outer layer and the town's edge growth required to be mixed with various activities, such as residential and commercial areas, new industrial sector and public center, and new town centers to accommodate the liveliness of the activities. The placemaking of the central part of the city 
is well contained. Still, new facilities such as the sports city on the southern part of Palembang need more diverse activities to support the concept of Placemaking. The findings also show that the housing's fast growth required to be followed by diversity in activities. If the city's growth is carried out in this condition, the quality of the space will undoubtedly be diminishing over time.
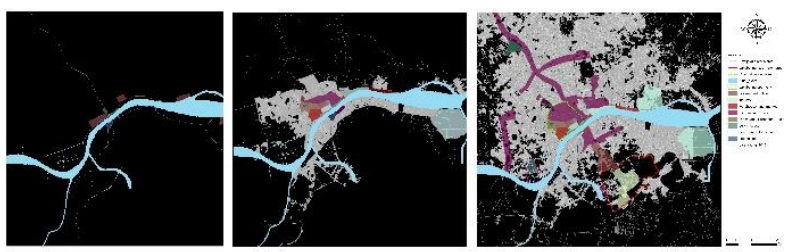

Source: Author, 2018

Figure 12. Land use Pattern morphological map of Palembang.

The image of the city of Palembang has always been associated with the Sriwijaya Empire's greatness, yet today the reminiscence of the great empire is yet to be seen. The images of traditional buildings are those of Rumah Limas, traditional wooden houses with the age of 200, and some are still standing strong in parts along the Musi River. The wooden house is an indication that strong memory and symbolism are being maintained in society.

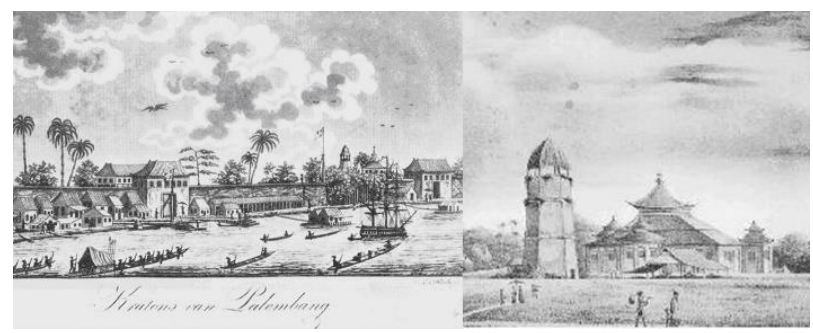

Figure 13: Image of the first morphological phase: The center of Palembang, The fort of Benteng Kuto Besak and the Grand Mosque of Palembang.

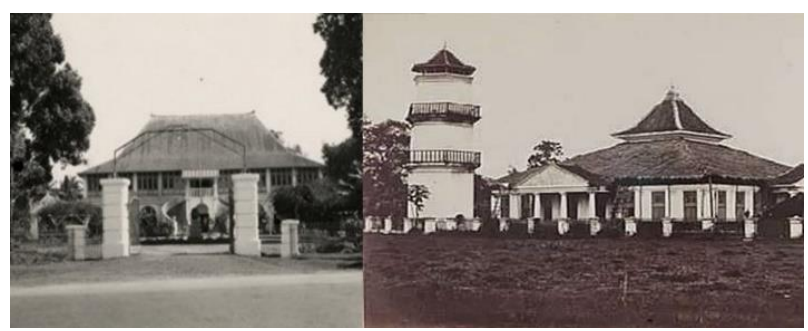

Figure 14: Image of the second morphological phase: Benteng Kuto Besak was transformed as a colonial governing center and the Grand Mosque of Palembang was infused with colonial style facade.

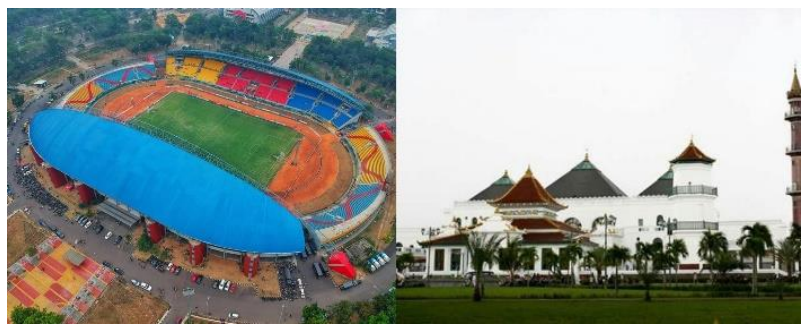

Figure 15: Image of the third morphological phase: The added new center of Jakabaring sport city on the hilir part of Palembang and the Grand Mosque of Palembang was added new building to accommodate the increase of population.

The strong symbols in the modern buildings in Palembang are the use of Songket figures in the new building exterior to show the buildings' identity. From the spatial configuration point of view, the creation of a district that is associated with a particular image of the past is still weak. Certain places are kept well maintained by the government, but other areas are being neglected, and heritage buildings are being destroyed. Earlier in 2017, a traditional heritage market called the state government was demolishing the Cinde market to create a new and modern market. The Palembang heritage community strongly refuted the act because the old market represents the pre-independence market of Palembang.

The city's landmark's historical evolution shows some Landmarks are kept intact from the first morphological phase. The landmarks were in the form of historical archeological sites reminiscent of the Sriwijaya Empire. The second morphological phase of the city's landmark was buildings from the colonial era. The building style and symbols were the combinations of European Colonial style with a mixture of tropical housing. The image of the colonial house and commercial area in the city created a strong colonial identity of Palembang's town. The center of the city, the Benteng Kuto Besak and also the Grand Mosque of Palembang, also established a strong 
centrality for a city that is growing into a radial form. The Image of Palembang city was initially linear in its form. Given the growth, we could conclude that even though the form was linear, the town always has a central point: the Keraton Kuto Besak and the Grand Mosque of Palembang with its public spaces. The third morphological phase's placemaking quality shows that there are numerous new landmarks added to the city.
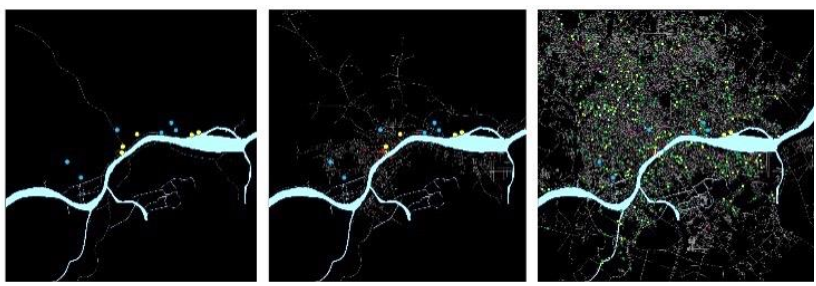

Source: Author, 2018

Figure 16. Landmark Pattern morphological map of Palembang.

The significant rise of landmarks was also followed by the increase and population and urbanization to the city. The new landmark is showing more to the image of modernity of commercial and hotel function. The central district of the city has a sharp image and identity with the Ampera Bridge that spread across the Musi River, but the image that is created in the outer edge of the city is blurred without strong ties and connection with the historical image of the city.

\subsection{Modern branding of Palembang and its implications}

The city has changed drastically after having the National Sporting event / Pekan Olahraga Nasional (PON) in 2004. Since the sporting event, the government is creating Palembang as one of the sports central in Indonesia. The new complex of a sporting venue called Jakabaring sports city is designed with complete sporting facilities. The Jakabaring sports facility is continuously growing and has held various sporting events from local and even international sporting events such as the Asian
Games in August 2018. The shift from a traditional and colonial port city into the Palembang sports city has impacted the city's policy and growth.

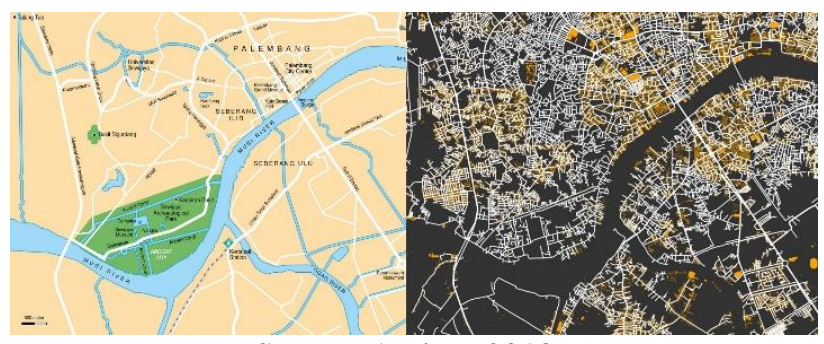

Source: Author, 2018

Figure 17: the Karanganyar site (shown in green), believed to be the site of Sriwijaya garden of waterways, reservoir and floating islands. The comparison figure ground and building map shows the difference of road transformation that affected the connectivity of the site to the city.

The city is now growing and turning into a modern city with the need for modern facilities. A new Light Rapid Transit is directly connecting the airport straight to the Jakabaring sports city. New buildings that are mostly commercial facilities and hotels are being constructed to meet the city's needs and demands. Besides the town's fast growth, old buildings and heritage sites are being neglected and becoming obsolescence. The rapid growth of the city also created urban sprawl. In Figure 17, we could see that the heritage site and district of Karanganyar have been transformed with new connecting roads and sparse housing. The housing is disrupting the spatial configuration of the heritage area of the city. Many similar heritage sites suffer the same as the Karanganyar site in Palembang. The growth is not in tune with maintaining the old building and creating a disruptive blending between the new and old buildings, thus creating less diversity because of the destruction of the old Urban fabric.

\section{CONCLUSION}


4.1. Importance of placemaking to continue creating successful place for the city.

By utilizing the spatial configuration tools and the place making theories, it was possible to study the transformation of morphological phases and the historical evolution of Palembang city. The study on the complexity of street pattern has shown its impact on Palembang's form. The diversity and activity of Palembang's land use also show that over time the modern Palembang have dissolved into a multinucleated city where old buildings are being demolished. Promoting vibrant activity and related historical activities will enhance the city's meaning. Symbolism and memory of the Landmarks should also be controlled and contained to preserve the placemaking like a city.

Table 1. Street Pattern, Land us, and landmark summary

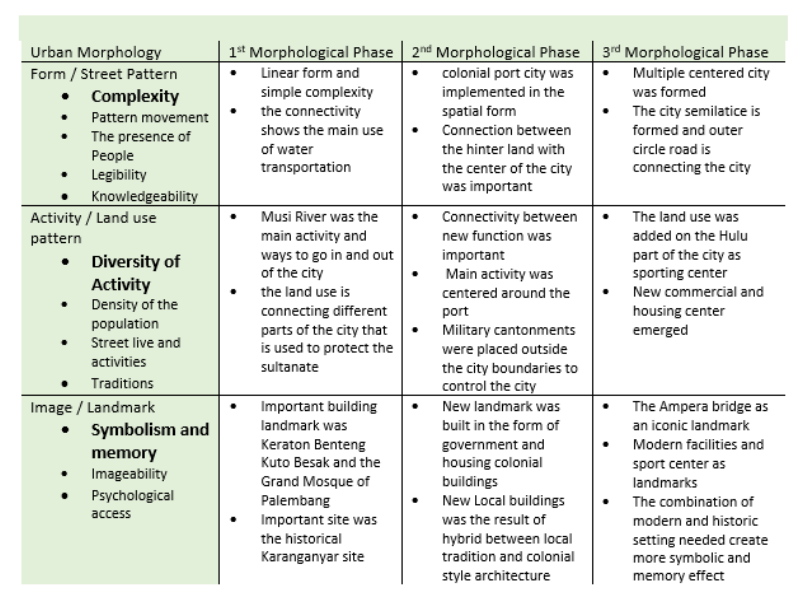

We were able to identify the historical evolution of placemaking as improving or diminishing by evaluating the city's form, activity, and image. Although further simulation and case study research are needed to verify the theory, this initial finding could indicate the quality of the city's historical evolution. More research is required to control the city's development because the city will continue to grow, and essential parts of the city will also continue to evolve. However, with the knowledge of the morphology phase, we could find out that some cities' persistent parts are possible for future Historic Urban Landscape development. Research had also been done about the morphology of settlements along the Musi river, which proved to be valuable to promote success for building typology, orientation, and how a community responds to nature [38].

\subsection{Acknowledging the historic city and spatial configuration.}

The findings also show a shift in the centrality of the city from its original layout. During the first and second morphological phases, the town's centrality is around the Benteng Kuto Besak area and the ports. Because of the city's dispersed development, the modern morphological phase shows the centrality of the street pattern moved to the hinterland part of the town. The city's growth is an indicator that the development is no longer only focusing on the heritage part of the town, and new central points were generated to create diverse growth in the city. The transformation and morphological phases of the city shows the importance of a different era of the city. Every phase of the development shows that the city changes might be because of political, social, and economy that affected the city's spatial configuration. By the significance of the historical part, this paper suggests that the city's boundaries should always be preserved and promote creating the placemaking to the city. The study also revealed that the center part of Palembang is the Benteng Kuto Besak area. This site is significant to Palembang's identity, and future planning and development should always reflect this part of the city. Another finding shows that the Karanganyar part is not being preserved, despite its significant importance on the city's history. The development pattern offers a disruptive connection to the area. This research suggests that the Karanganyar area should be well protected, preserved, and the site also plays an essential element for the city's quality of placemaking. 


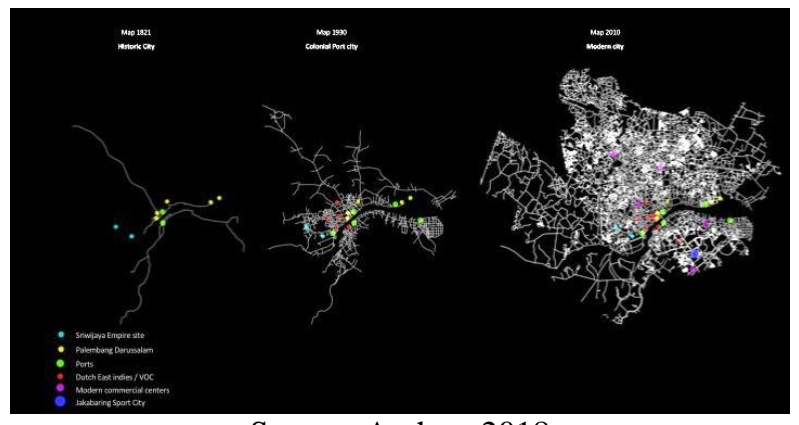

Source: Author, 2018

Figure 18: shows the transformation of spatial configuration of Palembang within the administrative boundaries. The dots show the important buildings in different eras.

The limitation of this paper is due to the cartographic differences between the old and new maps. Georeferencing was applied on the GIS map by assigning spatial coordinates on each map; land use and landmarks were also applied and have not changed coordinated from each morphological phase.

The map used in this paper was also acquired from OpenStreetMap, even though some differences on the detailed coordinate due to the different methods of old cartographic maps and today's GIS standard became a graphical limitation on this study. Nevertheless, the cartographic differences do not affect the outcome of this research. For future research, the author would like to suggest street pattern comparisons between contextual cities that could show the result of long-term evolution and the measurement of centrality to calculate the changes of integration in cities' street network.

\section{Acknowledgement}

The author gratefully acknowledges Dr. Mahbub Rashid for the discussion on this research by showing the choices in methods that are available for spatial data analysis. The writer also believes in the Urban Growth and Sprawl group's incredible insight and fruitful discussions on spatial analysis methods and data resources.

\section{References}

[1] Kostof S. The city assembled. Elem Urban Form Hist.

[2] Jacobs AB. Great streets.

[3] Alexander C. A city is not a tree. Sustasis Press/Off The Common Books, 2017.

[4] Bosselmann P. Urban transformation: Understanding city form and design. Island Press, 2012.

[5] Hillier B. The genetic code for cities: is it simpler than we think? In: Complexity theories of cities have come of age. Springer, 2012, pp. 129-152.

[6] Fuller M, Moore R. The death and life of great American cities. Macat Library, 2017.

[7] Cullen G. Townscape. Architectural Press, 1961. [8] Carmona M, Heath T, Tiesdell S, et al. Public places, urban spaces: the dimensions of urban design. Routledge, 2010.

[9] Montgomery J. Making a city: Urbanity, vitality and urban design. J Urban Des 1998; 3: 93-116.

[10] Rashid M, Bindajam AAA. Space, movement and heritage planning of the historic cities in Islamic societies: Learning from the Old City of Jeddah, Saudi Arabia. Urban Des Int 2015; 20: 107-129.

[11] Corcoran P, Mooney P, Bertolotto M. Analysing the growth of OpenStreetMap networks. Spat Stat 2013; 3: $21-32$.

[12] Arsanjani JJ, Zipf A, Mooney P, et al. An introduction to OpenStreetMap in geographic information science: Experiences, research, and applications. In: OpenStreetMap in GIScience. Springer, 2015, pp. 1-15.

[13] Brown LJ, Dixon D, Gillham O. Urban design for an urban century: Placemaking for people. Wiley Hoboken, NJ, 2009.

[14] Narvaez L, Penn A, Griffiths S. Creating Urban Place: Re-thinking the Value of Residential and Commercial Use in Urban Street Networks. Spaces Flows Int J Urban Extra Urban Stud; 2.

[15] Alobaydi D, Rashid M. A Study Of The Morphological Evolution Of The Urban Cores Of Baghdad In The 19th And 20th Century.

[16] Jacobs J. The death and life of great American cities. New York, NY: Random House, 1961.

[17] Marshall S, Gil J, Kropf K, et al. Street network studies: from networks to models and their representations. Netw Spat Econ 2018; 18: 735-749.

[18] Oliveira V, Monteiro C, Partanen J. A comparative study of urban form. Urban Morphol 2015; 19: 73-92.

[19] Widodo J. Historical morphology of coastal cities in Southeast Asia. In: Routledge Handbook of 
Urbanization in Southeast Asia. Routledge, 2018, pp. 391-399.

[20] Shateh H, Rashid M. The Relationship between the Governmental and Syntactic Cores: The case of Tripoli, Libya.

[21] Conzen MP. Core concepts in town-plan analysis. In: Teaching Urban Morphology. Springer, 2018, pp. 123-143.

[22] Lynch K. The image of the city. MIT press, 1960.

[23] Yi-ren S. Necessity of city image research from the aspect of city characteristic [J]. Urban Probl 2004; 3:

003.

[24] Smith A. Conceptualizing city image change: the 're-imaging' of Barcelona. Tour Geogr 2005; 7: 398-423.

[25] Rapoport A. Local environments in a global context. Ekistics 2006; 122-131.

[26] Byrne D. Western hegemony in archaeological heritage management. Hist Anthropol 1991; 5: 269-276.

[27] Kosambi M, Brush JE. Three colonial port cities in India. Geogr Rev 1988; 32-47.

[28] Bowden MJ. The Internal Structure of the Colonial Replica City: San Francisco and Others. In: Unpublished paper presented to the annual conference of the Association of American Geographers, Kansas City. 1972.

[29] Hornsby SJ. Discovering the mercantile city in South Asia: the example of early nineteenth-century Calcutta. J Hist Geogr 1997; 23: 135-150.

[30] Ashworth GJ. Heritage Planning: an Approach to Managing Historic Cities [In:] Managing Historic Cities. Int Cult Cent Kraków 1993; 27-47.

[31] Poulios I. Moving beyond a values-based approach to heritage conservation. Conserv Manag Archaeol Sites 2010; 12: 170-185.

[32] Tagliacozzo E. An urban ocean: notes on the historical evolution of coastal cities in greater Southeast Asia. J Urban Hist 2007; 33: 911-932.

[33] Wolters OW. Early Indonesian commerce: a study of the origins of Śrivijaya. Cornell University Press, 1967.

[34] Coedès G, Damais L-C. Sriwijaya: history, religion \& language of an early Malay polity. Kuala Lumpur: Malaysian Branch Royal Asiatic Society, 1992. [35] Hanafiah D. Kesultanan Palembang Darussalam. Dalam Jajaluddin Ed Petunjuk Kota Plb.

[36] Santun DIM, Purwanto B. Produksi dan reproduksi simbolik:: Memaknai konstruksi fisik dan ideologis Kota Palembang dari kolonial ke pascakolonial, 1930-1960-an. PhD Thesis, Universitas Gadjah Mada, 2009.

[37] Manguin P-Y. 'Welcome to Bumi Sriwijaya'Or the Building of a Provincial Identity in Contemporary
Indonesia. Asia Research Institute, National University of Singapore Singapore, 2008.

[38] Oktarini MF. The Settlement Morphology along The Musi River. IJBESR; 97-104. 
(This page is intentionally left blank) 